\title{
Greenhouse gas emission intensity from Indonesian livestock sector
}

Eska Nugrahaeningtyas - Chun-Youl Baek Jung-Hwan Jeon • Jun-Ik Song • Kyu-Hyun Park

Nugrahaeningtyas E - Park KH (Corresponding author)

College of Animal Life Sciences, Kangwon National University, Chuncheon 24341, Republic of Korea.

email: kpark74@kangwon.ac.kr

\section{Baek CY}

Center for Resources Information \& Management, Korea Institute of Industrial Technology, Seoul 06211, Republic of Korea.

\author{
Jeon JH \\ Animal Environment Division, National Institute of Animal \\ Science, RDA, Wanju 55365, Republic of Korea.

\section{Song JI} \\ Division of Animal Husbandry, Yonam College, Cheonan \\ 31005, Republic of Korea.
}

\section{Received: March 28, 2018 • Revised: June 04, 2018 • Accepted: June 05, 2018}

\begin{abstract}
The objectives of this study were to examine the trends of greenhouse gas (GHG) emission intensity (EI) from livestock sector in Indonesia, and also to suggest mitigation measures for the emissions. GHG emissions were calculated by using 2006 Intergovernmental Panel on Climate Change Guideline (2006 IPCC GL) Tier 1 method based on carbon dioxide equivalent (CO2eq) with default values except for Indonesian livestock population. GHG EI (emissions intensity) of livestock sector in Indonesia was calculated by dividing total GHG emissions by Indonesian meat production from livestock commodities. In 2015, beef cattle contributed $66.99 \%$ from total GHG emissions from livestock sector, followed by goat $(8.38 \%)$, sheep $(7.40 \%)$, buffalo $(6.89 \%)$, swine $(5.03 \%)$, broiler chicken $(3.80 \%)$, and horse $(0.72 \%)$. However, in 2015, buffalo showed the highest EI (kgCO2eq/kg meat) by 6.44 , followed by beef cattle (5.88), sheep (4.69), goat (4.07), swine (3.50), horse (3.09), and broiler chicken (0.38). EIs from swine, goat, sheep, broiler chicken, horse, beef cattle, and buffalo decreased by $60.77 \%$, $58.59 \%, 46.68 \%, 21.30 \%, 18.15 \%, 19.94 \%$, and $13.13 \%$ from 2000 to 2015, respectively. Results of GHG emissions and GHG EIs from each livestock category in Indonesia shown the improvement direction in order to mitigate GHG emission. Therefore, Indonesian government should focus on the beef cattle and buffalo that are a high contribution on GHG emissions and high EI by increasing the efficiency of livestock rearing management such as livestock health, genetic, diets, and environment.
\end{abstract}

Keywords: climate change, IPCC, meat production, mitigation, national inventory report

\section{Introduction}

Since pre-industrial era, the growth of economic and population has driven the increase of anthropogenic greenhouse gas $(\mathrm{GHG})$ emissions. Methane $\left(\mathrm{CH}_{4}\right)$ and carbon dioxide $\left(\mathrm{CO}_{2}\right)$ levels have increased by $148 \%$ and $38 \%$, respectively, as of 2009, above pre-industrial levels, resulting in global warming and an increase of the average temperature of the earth's surface by $0.6^{\circ} \mathrm{C}$ since the late 1800 s (Watson et al 2001). In 2010, total anthropogenic GHG emission was $49 \pm 4.5$ gigatonne $\mathrm{CO}_{2}$ equivalent per year $\left(\mathrm{Gt} \mathrm{CO}_{2}\right.$ eq/year) (Watson et al 2001) and agriculture sector contributed 10-12\% of the global GHG emissions (IPCC 2014). Greenhouse gas emissions from livestock sector include $\mathrm{CH} 4$ and nitrous oxide $\left(\mathrm{N}_{2} \mathrm{O}\right)$. Methane is emitted from two sources, enteric fermentation, and manure management. Methane is produced by herbivores as a by-product of enteric fermentation, a digestive process by which carbohydrates are broken down by microorganisms into simple molecules for absorption into the bloodstream (IPCC 2006). Methane emission from manure management is produced during the anaerobic decomposition of the manure. Its formation depends on several factor such as animal numbers, waste production per animal, and further, how the manure is managed (IPCC 2006). Nitrous oxide emissions occur via combined nitrification and denitrification of nitrogen contained in the manure, known as direct $\mathrm{N}_{2} \mathrm{O}$ emissions, and also as a result from volatile nitrogen losses that occur primarily in the forms of ammonia and $\mathrm{NO}_{\mathrm{x}}$, known as indirect $\mathrm{N}_{2} \mathrm{O}$ emissions (IPCC 2006).

Population growth, increases in per capita consumption and changes in diets leading to the consumption of more livestock products are the main drivers of agriculture product demand growth (Alexandratos and Bruinsma 2012). Demand for meat and milk is set to double by 2050 (FAO 2012). This leads to an increase of livestock population and as a result, GHG emissions from livestock sector increases. Mitigation for GHG emissions can be applied in various level, including in commodity level. Commodity-specific assessment helps to show the potential impact of promising farm mitigation 
measures when extrapolated to the whole industry (Verge et al 2009). One option for reducing GHG emissions from agriculture is to minimize the impact of various commodities on the environment (Verge et al 2009). In the context of human food security, the most relevant measure is 'emissions intensity' which expresses the quantity of gases produced per animal for a unit of production. This measurement most accurately reflects the management, feeding and manure systems of livestock in developing countries and the effects of given mitigation practices (Gerber et al 2013).

Indonesia's agriculture contributed $5 \%$ of national GHG emissions, with the emissions from enteric fermentation and manure management was counted for $18.14 \%$ and $2.57 \%$ of agricultural contribution in 2001 (MoE 2013). The meat consumption in Indonesia increased by $51.9 \%$ from 4.2 $\mathrm{kg} /$ capita/year in 2009 to $6.4 \mathrm{~kg} / \mathrm{capita} /$ year in 2015 (MoA 2013; MoA 2016). The increase of meat consumption drove the increase of livestock population to fill the national meet demand. In 2015, total livestock population in Indonesia increased by $40.08 \%$ than the population in 2000 (MoA 2001; MoA 2016). The largest population of livestock in Indonesia is chickens, followed by duck, goat, sheep, beef cattle, swine, buffalo, dairy cattle, and horse.

Therefore, this study was conducted to examine the trends of the emission intensities of livestock commodities in Indonesia and to suggest the mitigation measures for the emissions. The GHG emissions include $\mathrm{CH}_{4}$ emissions from enteric fermentation and manure management, also $\mathrm{N}_{2} \mathrm{O}$ emissions from manure management.

\section{Materials and Methods}

Data from Statistic on Livestock (MoA 2001; MoA 2006), Statistic of Livestock and Animal Health (MoA 2013; MoA 2016), and 2006 Intergovernmental Panel on Climate Change Guideline (2006 IPCC GL) Tier 1 method were used to calculate emissions from livestock in Indonesia. Although Tier 2 and Tier 3 methods are generally considered to be more accurate, they require a detailed information about livestock in the country which is not available in Indonesia. In 2006 IPCC GL the emissions from livestock sector consist of three sources: $\mathrm{CH}_{4}$ from enteric fermentation, $\mathrm{CH}_{4}$ from manure management, and $\mathrm{N}_{2} \mathrm{O}$ from manure management. The total emissions from livestock sector were calculated using total livestock population in Indonesia. For emission intensity, the emissions from the total number of slaughtered livestock (MoA 2011) were used. However, the number of slaughtered swine from the statistic showed unreasonable number because the carcass weight reached more than $100 \mathrm{~kg}$ when the meat production was divided by the number of slaughtered animals. Therefore, the number of slaughtered swine (Table 1) was calculated using equation from Livestock and Animal Health Data Collection Guideline (MoA 2011) below:
$\mathrm{Pt}=\mathrm{Po}+\mathrm{B}-\mathrm{D}-\mathrm{S}-\mathrm{E}+\mathrm{I}$

where $\mathrm{Pt}$ is animal population in year $\mathrm{t}$, Po is early population in year $t$ or last population from year before $t, B$ is birth of livestock in year $\mathrm{t}$ (Po times birth percentage), $\mathrm{D}$ is death of livestock in year $\mathrm{t}$ (Po times death percentage), $\mathrm{S}$ is slaughtered livestock, $\mathrm{E}$ is exported livestock, and $\mathrm{I}$ is imported livestock.

The number of broiler chicken in 2000 was included in the poultry population, so that, the number of population in 2000 was calculated using the percentage of broiler chicken in 2005 (67.3\% of total poultry population). The livestock sector included in this study was the meat-producing commodity (beef cattle, buffalo, sheep, goat, swine, horse, and broiler chicken). Other commodities such as dairy cattle, native chicken, layer chicken, and duck were not included because these commodities are considered to be the dual-purpose commodity, producing meat, milk, and/or egg.

Methane emissions from enteric fermentation were calculated by multiplying the number of livestock with the $\mathrm{CH}_{4}$ emission factor (EF) for enteric fermentation from 2006 IPCC GL for each livestock category. Default EFs based on the regional characteristic in Asia were applied for dairy and beef cattle, default EFs for other livestock were based on developing countries characteristic. For $\mathrm{CH}_{4}$ from manure management, the equation to estimate $\mathrm{CH}_{4}$ emissions from manure management was the result of multiplication of the number of animals with $\mathrm{CH}_{4} \mathrm{EF}$ for manure management from 2006 IPCC GL for each livestock category. Default EFs based on the regional characteristic in Asia with annual temperature $26^{\circ} \mathrm{C}$ from were applied for beef cattle, swine, and buffalo. Default EFs for other livestock were based on developing countries characteristic.

Even though $\mathrm{N}_{2} \mathrm{O}$ emissions consist of direct and indirect emissions, in this study, only direct emission was calculated for the emissions from the livestock sector. The equation to calculate $\mathrm{N}_{2} \mathrm{O}$ emissions was:

$\mathrm{N}_{2} \mathrm{O}_{\text {DMM }}=\left[\sum_{S}\left[\sum_{T} N_{(T)} \bullet N_{e x(T)} \bullet M S_{(T, S)}\right] \bullet E F_{3 S}\right] \bullet \frac{44}{28}$

where $\mathrm{N}_{2} \mathrm{O}_{\text {DMM }}$ is direct $\mathrm{N}_{2} \mathrm{O}$ emissions from manure management in the country $\left(\mathrm{kg} \mathrm{N}_{2} \mathrm{O} /\right.$ year $), \mathrm{N}_{(\mathrm{T})}$ is number of head of livestock species per category $\mathrm{T}$ in the country, $\mathrm{N}_{\mathrm{ex}(\mathrm{T})}$ is annual average $\mathrm{N}$ excretion per head of species per category $\mathrm{T}$ in the country ( $\mathrm{kg} \mathrm{N} /$ animal/year), $\mathrm{MS}_{(\mathrm{T}, \mathrm{S})}$ is fraction of total annual nitrogen excretion for each livestock species per category $\mathrm{T}$ that is managed in the manure management system $\mathrm{S}$ in the country, $\mathrm{EF}_{(3 \mathrm{~S})}$ is emission factor for direct $\mathrm{N}_{2} \mathrm{O}$ emissions from manure management system $\mathrm{S}$ in the country ( $\mathrm{kg} \mathrm{N}_{2} \mathrm{O}-\mathrm{N} / \mathrm{kg} \mathrm{N}$ ). Default $\mathrm{N}_{\mathrm{ex}(\mathrm{T})}, \mathrm{MS}_{(\mathrm{T}, \mathrm{S})}$, and $\mathrm{EF}_{(3 \mathrm{~S})}$ from 2006 IPCC GL were used to estimate $\mathrm{N}_{2} \mathrm{O}$ emissions. 
Emission intensity represents the amount of emissions by livestock per production unit. In this study, emission intensity was based on the emissions from enteric fermentation and manure management, per meat production unit. Meat production data were obtained from Statistic on Livestock (MoA 2001; MoA 2006) and Statistic of Livestock and Animal Health (MoA 2013; MoA 2016). Meat production is defined as the carcass resulting from livestock slaughtered plus edible offal during a certain period and in a certain region
(MoA 2011). The emissions for emission intensity calculation were based on the emissions from the number of slaughtered livestock in Indonesia (beef cattle, buffalo, sheep, goat, swine, broiler chicken, horse). Hereafter, the emissions were divided by the meat production from each livestock category. The use of meat production in emission intensity measurement can reflect the management, feeding and manure systems of livestock.

Table 1 Calculation for the number of livestock slaughtered for swine.

\begin{tabular}{cccccccccc}
\hline Year & $\begin{array}{c}\text { Po } \\
\text { (heads) }\end{array}$ & $\%^{*}$ & $\begin{array}{c}\mathrm{B} \\
\text { (heads) }\end{array}$ & $\%^{*}$ & $\begin{array}{c}\mathrm{D} \\
\text { (heads) }\end{array}$ & $\begin{array}{c}\mathrm{E} \\
\text { (heads) }\end{array}$ & $\begin{array}{c}\mathrm{I} \\
\text { (heads) }\end{array}$ & $\begin{array}{c}\text { Pt } \\
\text { (heads) }\end{array}$ & $\begin{array}{c}\mathrm{S} \\
\text { (heads) }\end{array}$ \\
\hline 2000 & $7,041,820^{\mathrm{b}}$ & 95.12 & $6,698,179$ & 19.59 & $1,379,493$ & $443,322^{\mathrm{b}}$ & $227,263^{\mathrm{b}}$ & $5,356,834$ & $6,787,614$ \\
2005 & $5,980,148^{\mathrm{c}}$ & 95.12 & $5,688,317$ & 19.59 & $1,171,511$ & $1,145,434^{\mathrm{c}}$ & $239,341^{\mathrm{c}}$ & $6,800,698$ & $2,790,163$ \\
2010 & $6,975,000^{\mathrm{d}}$ & 95.12 & $6,634,620$ & 19.59 & $1,366,403$ & $226,533^{\mathrm{d}}$ & $219,694^{\mathrm{d}}$ & $7,477,000$ & $4,759,379$ \\
2015 & $7,694,000^{\mathrm{e}}$ & 95.12 & $7,318,533$ & 19.59 & $1,507,255$ & $486,541^{\mathrm{e}}$ & $202,971^{\mathrm{e}}$ & $7,808,087$ & $5,413,621$
\end{tabular}

Source: Department of Agriculture (2001; 2006), Ministry of Agriculture (2013; 2016); ${ }^{*}$ Based on the survey of livestock household 2008 by BPS-Statistic Indonesia and Directorate General of Livestock Services Ministry of Agriculture, 2016.

\section{Results and Discussion}

The highest emitter of GHG emissions from livestock sector in 2015 was beef cattle (Figure 1). Beef cattle was the highest emitter $(66.99 \%$ of total GHG emissions from livestock sector in Indonesia) in 2015, followed by goat $(8.38 \%)$, sheep $(7.40 \%)$, buffalo $(6.89 \%)$, swine $(5.03 \%)$, broiler chicken $(3.80 \%)$, and horse $(0.72 \%)$. This high share of GHG emissions was caused by the high $\mathrm{EF}$ in $\mathrm{CH}_{4}$ from enteric fermentation due to high conversion from feed energy to methane, $\mathrm{CH}_{4}$ from manure management due to the high volatile solids (VS), and also high nitrogen excretion $\left(\mathrm{N}_{\mathrm{ex}}\right)$ due to the coarse feed. The biggest increase from $\mathrm{CH}_{4}$ emissions from developing countries is usually associated with the expansion of beef and dairy cattle production in these countries (Caro et al 2014).

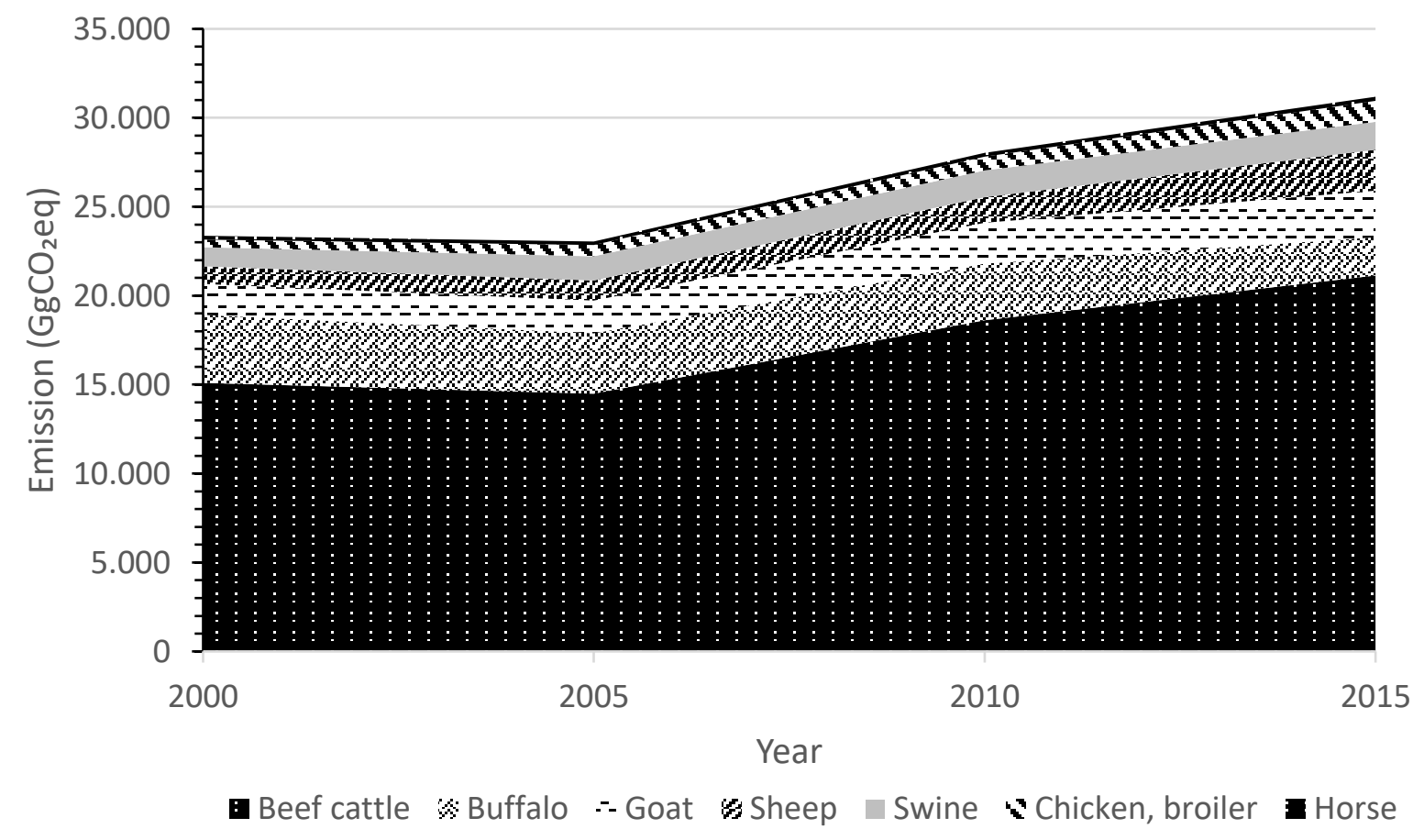

Figure 1 Greenhouse gas emission from livestock sector in Indonesia from year 2000 to 2015. 
High emission intensities were shown by ruminants, such as buffalo, beef cattle, sheep, and goat (Figure 2). In 2015, emission intensities $\left(\mathrm{kgCO}_{2} \mathrm{eq} / \mathrm{kg}\right.$ meat $)$ in buffalo, beef cattle, sheep, and goat were 6.44, 5.88, 4.69, and 4.07, respectively. Emission intensities of other livestock such as swine and horse were 3.50 and 3.09, respectively. High emission intensity is usually caused by the low productivity in each commodity compared to the emission. Low productivity is highly related to the management practices. In Indonesia, ruminants, mainly buffalo and big cattle, are mostly raised by small-scale farmers, often with 1-2 buffaloes (Triwulaningsih and Praharani 2018) or 2-3 cattle (Priyanti et al 2012) per household. Also, traditionally, farmers in Indonesia raise the livestock as for-profit and workforce in the field. Buffaloes are raised as draught power animal, food supplies and source of manure, ritual ceremony animal, especially in North Sumatra and South Sulawesi and some other regions in Indonesia.
Farmers raise buffalo for draught power and profit, so that the old buffalo are culled and slaughtered (Triwulaningsih and Praharani 2018). The feed for the draft animal in the rural farming system is relied on mixed-crop farming system, where practically buffalo are grazed on marginal lands such as rice buds, highway shoulder, scrub forest, as well as utilizing crop wastes such as rice straws (Triwulaningsih and Praharani 2018). Similar to buffalo, small-scale cattle production is well integrated with intensive crop production, consequently, crop residues and by-products are a major source of cattle feed, while cattle still provide draught power and manure for cropping (Priyanti et al 2012). High GHG emission intensities are driven by low animal productivity across large areas of arid lands, the use of low-quality feeds, feed scarcity, and animals with low productive potential that are often used for draft power and to manage household risk, as well as for production (Herrero et al 2016).

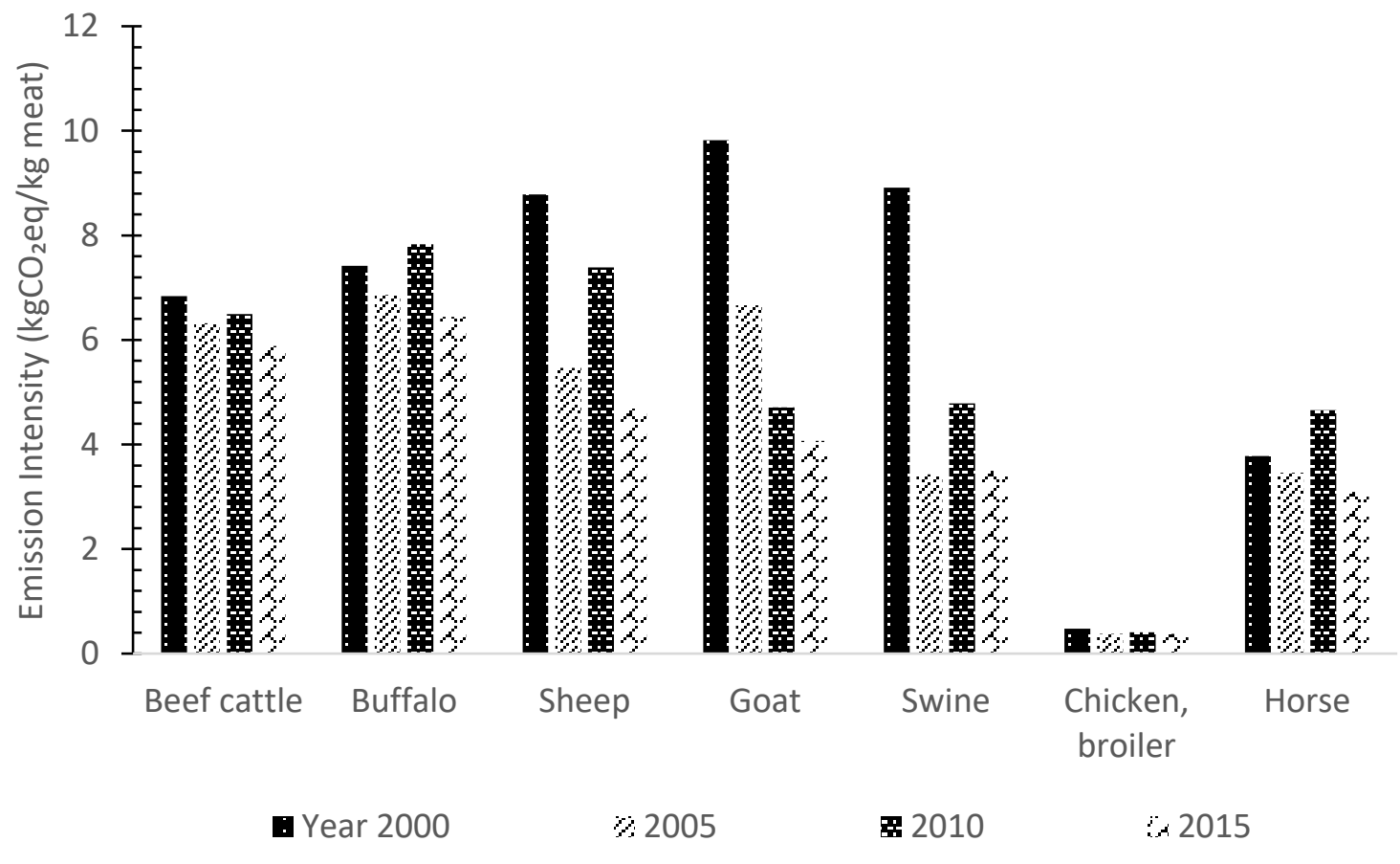

Figure 2 The trends of GHG emission intensity from year 2000 to 2015 based on meat production from slaughtered livestock in Indonesia.

On the other hand, the lowest emission intensity were shown by broiler chicken with $0.38 \mathrm{kgCO}_{2} \mathrm{eq} / \mathrm{kg}$ meat. The low emission intensities in chicken was caused by the equality of the increased GHG emissions and the increased production. This indicates that the efficient production can result in the decline of emission intensity (Herrero et al 2013). Moreover, the production of swine and poultry is the most efficient (Herrero et al 2013) and the production of meat and eggs from monogastric has significantly lower emission intensities than milk and meat from ruminants. Low emission intensities are driven largely by the industrial pig and poultry sectors which consume high quality, balanced concentrate diets, and which tend to use animals of high genetic potential (Herrero et al 2013). In the application of livestock industry, enzymes are widely added to feeds for pigs and poultry, and these have contributed with breeding to have substantial gains in feed conversion efficiency that have been achieved (Thornton 2017).

Overall, the emission intensities from livestock in Indonesia reduced from 2000 to 2015 (Figure 2). Swine, goat, sheep, broiler chicken, horse, beef cattle, and buffalo showed a reduction of emission intensity by $60.77 \%, 58.59 \%, 46.68 \%$, 
$21.30 \%, 18.15 \%, 19.94 \%$, and $13.13 \%$, respectively. The decrease of the emission intensity showed that the livestock management in Indonesia has become more efficient, resulting in better production. This is also shown by the increase of carcass weight per livestock category from 2000 to 2015 (Table 2).

Table 2 Livestock production in Indonesia from year 2000 to 2015.

\begin{tabular}{|c|c|c|c|c|c|}
\hline \multirow[b]{2}{*}{ Livestock } & \multirow[b]{2}{*}{ Year } & \multirow{2}{*}{$\begin{array}{r}\text { Total } \\
\text { population } \\
\text { (heads) }\end{array}$} & \multicolumn{3}{|c|}{ Meat production } \\
\hline & & & $\begin{array}{l}\text { Total slaughter } \\
\text { (heads) }\end{array}$ & $\begin{array}{c}\text { Average } \\
\text { carcass weight } \\
(\mathrm{kg})\end{array}$ & $\begin{array}{c}\text { Total meat } \\
\text { production (tonnes) }\end{array}$ \\
\hline \multirow{4}{*}{ Beef cattle } & 2000 & $11,008,000$ & $1,695,374$ & 200.5 & 339,900 \\
\hline & 2005 & $10,569,000$ & $1,653,770$ & 216.9 & 358,700 \\
\hline & 2010 & $13,582,000$ & $2,068,706$ & 211.0 & 436,500 \\
\hline & 2015 & $15,420,000$ & $2,175,000$ & 233.0 & 506,700 \\
\hline \multirow{4}{*}{ Buffalo } & 2000 & 245,000 & 213,450 & 215.0 & 45,900 \\
\hline & 2005 & $2,128,000$ & 163,848 & 232.5 & 38,100 \\
\hline & 2010 & $2,000,000$ & 176,198 & 203.7 & 35,900 \\
\hline & 2015 & $1,347,000$ & 143,000 & 247.6 & 35,400 \\
\hline \multirow{4}{*}{ Sheep } & 2000 & $7,427,000$ & $1,873,368$ & 24.0 & 44,900 \\
\hline & 2005 & $8,327,000$ & $1,228,277$ & 38.5 & 47,300 \\
\hline & 2010 & $10,725,000$ & $1,574,826$ & 28.5 & 44,900 \\
\hline & 2015 & $17,025,000$ & 990,000 & 44.9 & 44,500 \\
\hline \multirow{4}{*}{ Goat } & 2000 & $12,566,000$ & $2,385,025$ & 14.0 & 33,400 \\
\hline & 2005 & $13,409,000$ & $2,451,584$ & 20.6 & 50,600 \\
\hline & 2010 & $16,620,000$ & $2,354,542$ & 29.2 & 68,800 \\
\hline & 2015 & $19,013,000$ & $1,919,000$ & 33.8 & 64,900 \\
\hline \multirow{4}{*}{ Swine* } & 2000 & $5,357,000$ & $1,459,214$ & 111.3 & 162,400 \\
\hline & 2005 & $6,801,000$ & $1,646,482$ & 105.5 & 173,700 \\
\hline & 2010 & $7,477,000$ & $1,563,353$ & 135.6 & 212,000 \\
\hline & 2015 & $7,808,000$ & $2,033,000$ & 162.4 & 330,200 \\
\hline \multirow{4}{*}{ Swine** } & 2000 & $5,357,000$ & $6,787,614$ & 23.93 & 162,400 \\
\hline & 2005 & $6,801,000$ & $2,790,163$ & 62.25 & 173,700 \\
\hline & 2010 & $7,477,000$ & $4,759,379$ & 44.54 & 212,000 \\
\hline & 2015 & $7,808,000$ & $5,413,621$ & 60.99 & 330,200 \\
\hline \multirow{4}{*}{$\begin{array}{l}\text { Chicken, } \\
\text { broiler*** }\end{array}$} & 2000 & $530,874,000$ & $530,874,000$ & 1.0 & 555,218 \\
\hline & 2005 & $811,189,000$ & $811,189,000$ & 1.3 & $1,080,500$ \\
\hline & 2010 & $986,872,000$ & $986,872,000$ & 1.2 & $1,214,300$ \\
\hline & 2015 & $1,528,329,000$ & $1,528,329,000$ & 1.3 & $2,030,900$ \\
\hline \multirow{4}{*}{ Horse } & 2000 & 412,000 & 7,219 & 138.5 & 1,000 \\
\hline & 2005 & 387,000 & 10,565 & 151.4 & 1,600 \\
\hline & 2010 & 419,000 & 17,790 & 112.4 & 2,000 \\
\hline & 2015 & 430,000 & 13,000 & 169.2 & 2,200 \\
\hline
\end{tabular}

Source: Department of Agriculture (2001; 2006), Ministry of Agriculture (2013; 2016) *The number of slaughtered animals based on livestock statistic; **The number of slaughtered animals based on calculation from Livestock and Animal Health Data Guideline 2011; *** Slaughtered population was considered as much as total population.

Several measures are needed in order to mitigate GHG emissions and maintain the efficiency of production. Indonesia, as a part of developing countries, tends to have low emission intensities from the developed country due to high emissions from livestock, low productivity, and a large number of animals. Conversely, the developed countries have high absolute emissions. Those countries, however, have improved livestock diets, genetics, health, and management practices (Herrero et al 2013) so that the emission intensity is low. Several options such as improving the genetic potential of animal for production, reproductive performance, health and live weight gain rates are among the most effective approaches for reducing GHG emissions per unit of product (Cottle et al 2011) while reducing the age of slaughter by increasing live weight gain rates significantly decreases GHG emissions per unit product in beef and other meat production systems (Zervas and Tsiplakou 2012). Another important mitigation option for livestock in developing countries, especially in ruminants, is the utilization of forages with high digestibility. When the digestibility of forages increases, 
conversion of feed energy to methane in enteric fermentation and manure excretion are reduced, and consequently the emissions of $\mathrm{CH}_{4}$ and $\mathrm{N}_{2} \mathrm{O}$ decreases (Forabosco et al 2017). Also, efficient and controlled manure management can be the mitigation strategies to lower the emission and then lower the emission intensity. In developing countries, just applying simple techniques such as piling, compacting, and covering the manure have positive effects on reducing the emissions and nutrient losses (Forabosco et al 2017).

\section{Conclusions}

In 2015, beef cattle was the highest contributor of total GHG emissions from livestock sector in Indonesian, meanwhile buffalo and broiler chicken had the highest and the lowest emission intensity, respectively. Moreover, the emission intensities from livestock sector in Indonesia showed a reduction from the year 2000 to 2015 and the highest reduction of emission intensity was showed by swine. The cause of the reduction was the intensification of the livestock industry and better management of livestock industry in Indonesia. Better management practices were also reflected by the increase of carcass weight per livestock category. However, the number of slaughtered swine should be reviewed in advance since the number from Indonesian Livestock Statistic was quite unreasonable. In the future, Indonesia is suggested to focus on better management of the ruminants, either large or small ruminants to increase the productivity. The concern of management practices, health, genetic, and diets may improve the productivity of livestock, while the proper manure management will help lower the emissions from livestock and help reduce the emission intensity from the livestock sector.

\section{Acknowledgements}

This work was carried out with the support of "Cooperative Research Program for Agriculture Science \& Technology Development (Project No. PJ01077601)", Rural Development Administration, Republic of Korea.

\section{References}

Alexandratos N, Bruinsma J. (2012) World agriculture towards 2030/2050: the 2012 revision. ESA Working paper. FAO. 12(3).

Caro D, Davis SJ, Bastianomi S, Caldeira K. (2014) Global and regional trends in greenhouse gas emissions from livestock. Climatic Change 12:203-216.

Cottle DJ, Nolan JV, Wiedemann SG. (2011) Ruminant enteric methane mitigation: a review. Animal Production Science 51:491514.

FAO (2018) Global Agriculture towards 2050. FAO http://www.fao.org/fileadmin/templates/wsfs/docs/Issues_papers/H LEF2050_Global_Agriculture.pdf. (Accessed 02 Mar 2018)
Forabosco F, Chitchyan Zn, Mantovani R. (2017) Methane, nitrous oxide emissions, and mitigation strategies for livestock in developing countries: A review. South African Journal of Animal Science 47: 268-280.

Herrero M., Henderson B, Havlík P, Thomton PK, Conant RT, Smith P, Butterbach-Bahl K. (2016) Greenhouse gas mitigation potentials in the livestock sector. Nature Climate Change 6, 452.

Herrero M, Havlík P, Valin H, Notenbaert A, Rufino MC, Thornton PK, Obersteiner M (2013) Biomass use, production, feed efficiencies, and greenhouse gas emissions from global livestock systems. Proceedings of the National Academy of Sciences 110:20888-20893.

Gerber PJ, Henderson B, Makkar, HP, (2013) Mitigation of greenhouse gas emissions in livestock production. A review of technical options for non- $\mathrm{CO}_{2}$ emissions. FAO.

IPCC (2014) Climate Change 2014: Mitigation of Climate Change. Contribution of Working Group III to the Fifth Assessment Report of the Intergovernmental Panel on Climate Change. Cambridge, United Kingdom and New York, USA: Cambridge University Press.

IPCC (2006) IPCC Guidelines for national greenhouse gas inventories. Prepared by the national greenhouse gas inventories programme, Eggleston HS, Buendia L. Publicado por: IGES, Japan.

MoE (Ministry of Environment) (2010) Indonesia second national communication under the United Nations Framework Convention on Climate Change. Jakarta: Indonesian Ministry of Environment.

MoA (Ministry of Agriculture) (2013) Livestock and animal health statistic. Jakarta: Directorate General of Livestock and Animal Health, Indonesian Ministry of Agriculture.

MoA (Ministry of Agriculture) (2016) Livestock and animal health statistic. Jakarta: Directorate General of Livestock and Animal Health, Indonesian Ministry of Agriculture.

MoA (Ministry of Agriculture) (2001) Department of Agriculture. Livestock Statistic. Jakarta: Directorate General of Livestock and Animal Health, Indonesian Ministry of Agriculture.

MoA (Ministry of Agriculture) (2006) Department of Agriculture. Livestock Statistic. Jakarta: Directorate General of Livestock and Animal Health, Indonesian Ministry of Agriculture.

MoA (Ministry of Agriculture) (2011) Pedoman pengumpulan data peternakan dan kesehatan hewan tahun 2011. Jakarta: Directorate General of Livestock and Animal Health, Indonesian Ministry of Agriculture.

Priyanti A, Hanifah VW, Mahendri IGAP, Cahyadi F, Cramb RA (2012) Small-scale beef cattle production in East Java, Indonesia. In Proceedings of the Australian Agricultural and Resource Economics Society annual conference' (AARES: Fremantle, WA).

Triwulaningsih E, Praharani L (2018) Buffaloes in Indonesia. Indonesian Research Institute for Animal Production; http://peternakan.litbang.pertanian.go.id/fullteks/lokakarya/pbptkbo 06-10.pdf?secure=1 (Accessed 02 Mar 2018)

Thornton PK (2017) Livestock production: recent trends, future prospects. Philosophical Transaction of The Royal Society B 465:2853-2867.

Verge XPC, Dyer JA, Desjardins RL, Worth D (2009) Long-term trends in greenhouse gas emissions from the Canadian poultry industry. Journal of Applied Poulty Research 18:210-222.

Watson, Robert T. (ed.) (2001) Synthesis Report: Contribution of Working Groups I, II, and III to the Third Assessment Report of the 
Intergovernmental Panel on Climate Change. Cambridge university press, 151

Zervas G, Tsiplakou E (2012) An assessment of GHG emissions from small ruminants in comparison with GHG emissions from large ruminants and mono gastric livestock. Atmospheric Environment 29:13-23. 